\title{
Transcription Factor SOX-3
}

National Cancer Institute

\section{Source}

National Cancer Institute. Transcription Factor SOX-3. NCI Thesaurus. Code C75515.

Transcription factor SOX-3 (446 aa, $\sim 45 \mathrm{kDa}$ ) is encoded by the human SOX3 gene. This protein plays a role in the modulation of gene transcription. 